\title{
Ureter Fissus
}

National Cancer Institute

\section{Source}

National Cancer Institute. Ureter Fissus. NCI Thesaurus. Code C123233.

A condition in which two ipsilateral ureters unite and drain into the bladder at a single ureteric orifice. 